Vol. 6 №. 1, Mei 2019 (pp. 90-103)

ISSN : 2580-6181 (Print), 2599-2481 (Online)

Available online at:

http://e journal. upi. edu/index. php/tarbawy/index

\title{
EFEKTIFITAS PENGGUNAAN METODE SHOW AND TELL TERHADAP PENINGKATAN PRESTASI BELAJAR SISWA (Studi Kuasi Eksperimen)
}

\author{
Resty Aprilia Fihrallah,* \\ Edi Suresman, dan Saepul Anwar
}

Universitas Pendidikan Indonesia (UPI), Indonesia

*E-mail: resty.aprilia@student.upi.edu

\begin{abstract}
This study discusses the effectiveness of the use of the Show and Tell method in improving the learning achievement of fourth grade students in Akblak subjects in Madarasah Diniyah Takmiliyah Awaliyah Wasilatunnaja in the 2015/2016 academic year. This research uses a quantitative method through an experimental approach with nonequivalent control group design. Based on the results of data analysis based on the normality test, homogeneity test, and $t$ test, it is known that the results of posttest, is normal and homogeneous, the sig (2-tailed) value of 0.145 with (df) 45 where $0.145>0.05$. Then, according to the basis of decision making in the independent sample t-test, it can be concluded that $\mathrm{Ho}$ is accepted and $\mathrm{Ha}$ is rejected, which means that there is no difference between the average learning outcomes of the experimental class and the control class. Which also shows that there is no significant difference in learning outcomes between the experimental class and the control class. In other words the show and tell method is not effective enough in improving student learning outcomes in moral subjects.
\end{abstract}

Keywords: Effectiveness, Show and Tell Methods, and Learning Acbievement

\begin{abstract}
Abstrak. Penelitian ini membahas tentang efektivitas penggunaan metode Show and Tell dalam meningkatkean prestasi belajar siswa kelas IV pada mata pelajaran Akblak di Madarasah Diniyah Takmiliyah Awaliyah Wasilatunnaja pada Tabun Ajaran 2015/2016. Penelitian ini menggunakan metode kuantitatif melalui pendekatan eksperimen dengan nonequivalent control group design. Berdasarkan hasil analisis data dengan berdasarkan pada uji normalitas, uji homogenitas, dan uji-t, diketabui bahwa hasil dari postest normal dan homogen, maka diperoleh nilai sig (2-tailed) sebesar 0,145 dengan (df) 45 di mana 0,145 > 0,05. Maka sesuai dasar pengambilan keputusan dalam uji independent sample t-test maka dapat disimpulkan $\mathrm{H}_{0}$ diterima dan $\mathrm{H}_{a}$ ditolak yang artinya bahwa tidak terdapat perbedaan antara rata-rata hasil belajar kelas eksperimen dan kelas kontrol. Yang juga menunjukkan bahwa tidak ada perbedaan yang signifikan hasil belajar antara kelas eksperimen dan kelas kontrol. Dengan kata lain metode show and tell ini tidak cukup efektif dalam meningkatkan hasil belajar siswa pada mata pelajara akblak.
\end{abstract}

Kata kunci: Efektivitas, Metode Show and Tell, Prestasi belajar

TARBAWY: Indonesian Journal of Islamic Education - Vol. 5 No. 2 (2017) |90 


\section{PENDAHULUAN}

Pendidikan merupakan hal yang terpenting dalam kehidupan manusia. Karena itu, setiap manusia berhak mendapat dan berharap untuk selalu berkembang dalam pendidikan. Setidaknya ada tiga alasan yang menjadikan pendidikan itu sangat penting dalam kehidupan manusia. Pertama, pendidikan merupakan proses pewarisan budaya, kedua, pendidikan sebagai pengembangan potensi manusia, dan ketiga, pendidikan sebagai penentu kualitas bangsa.

Pertama, pendidikan merupakan proses pewarisan budaya maksudnya adalah dengan pendidikan merupakan proses pewarisan budaya ialah manusia di sebut makluk budaya, karena manusia adalah sebagai subyek sekaligus objek kebudayaan. Hubungannya dengan pendidikan,maka manusia sebagai subjek pendidikan tidak bisa di lepaskan dari kebudayaan. Oleh karena itu dapat pula di katakan bahwa pendidikan merupakan proses pembudayaan untuk menjadikan manusia lebih baik dan bermakna, sementara itu manusia akan menghasilkan kebudayaan yang baik jika di topang oleh pendidikan yang luas. Dalam konteks inilah antara pendidikan tidak bisa lepas dari kebudayaan dan kebudayaan tidak lepas dari pendidikan.Pendidikan juga merupakan proses budaya untuk meningkatkan harkat dan martabat manusia.

Kedua, pendidikan sebagai pengembangan potensi manusia maksud-nya adalah menjaga dan mengerahkan fitrah atau potensi tersebut menuju kebaikan dan kesempurnaan, serta merealisasikan program tersebut secara bertahap. Pengembangan berbagai potensi manusia (fitrah) ini dapat dilakukan dengan kegiatan belajar, yaitu melalui institusiinstitusi. Belajar yang dimaksud tidak harus melalui pendidikan di sekolah saja, tetapi juga dapat dilakukan di luar sekolah, baik dalam keluarga maupun masyarakat ataupun melalui institusi sosial yang ada seperti televisi, radio, media sosial dan bahkan kehidupan masyarakat itu sendiri.

Ketiga, Pendidikan merupakan sarana strategis untuk meningkatkan kualitas suatu bangsa, karenannya kemajuan suatu bangsa dapat diukur dari kemajuan pendidikannya. Kemajuan beberapa negara di dunia ini tidak terlepas dari kemajuan yang di mulai dari pendidikannya, pernyataan tersebut juga diyakini oleh bangsa ini. Namun pada kenyataannya, sistem pendidikan Indonesia belum menunjukkan keberhasilan yang diharapkan.

Fungsi di atas lebih dijabarkan lagi oleh tujuan pendidikan dalan UU RI Nomor 20 Tahun 2003 Bab II pasal 3 mengemukakan bahwa pendidikan bertujuan untuk berkembangnya potensi peserta didik agar menjadi Manusia yang beriman dan bertakwa kepada Tuhan Yang Maha Esa, berakhlak mulia, sehat, berilmu, cakap, kreatif, mandiri, dan menjadi warga negara yang demokratis serta bertanggung jawab.

Suryadi (2011, hal. 168-169) menambahkan bahwa tujuan pendidikan adalah hal pertama dan terpenting bila akan merancang, membuat program, serta mengevaluasi pendidikan. Perogram pendidikan ditentukan oleh rumusan tujuan pendidikan. Dalam bahasa sederhana, mutu pendidikan akan segera terlihat pada rumusan tujuan pendidikan.

Salah satu ketercapaiannya tujuan pendidikan adalah dengan di adakannya lembaga, entah itu sekolah atau lembaga yang mendukung dengan keberhasilannya tujuan pendidikan. Dengan sekolah, seseorang yang asalnya tidak tahu akan menjadi tahu. Melalui sekolah atau salah satu pendukung lainnya juga seseorang akan bisa menambah ilmu.

Manusia dilahirkan dalam keadaan fitrah, yaitu potensi dasar yang dapat 
berkembang. Pada awalnya manusia diciptakan Allah SWT dalam keadaan tidak mengetahui apa-apa, sebagaimana firman Allah SW'T dalam surat An-Nahl ayat 78 .

Ayat tersebut menggambarkan bahwa manusia dilahirkan ke dunia ini dalam keadaan tidak mengetahui apaapa, ia diberi potensi yang ada dalam dirinya yaitu berupa pendengaran, pengihatan, dan hati. Tiga potensi inilah yang selanjutnya menjadi sumber bagi setiap manusia untuk mengembangkan dirinya menjadi insan kamil. Usaha untuk mengembangkan potensi yang ada pada manusia tersebut adalah melalui pendidikan.Akan tetapi permasalahan di atas dapat teratasi ketika tiga komponen berjalan menunjangkan potensinya dengan baik. Bukan hanya keluarga, masyarakat dan juga pemerintah pun bertanggung jawab terhadap pendidikan tersebut.

Sebagaimana kita ketahui bahwa pendidikan yang pertama kali kita dapatkan adalah dari keluarga. Dari mulai kita bisa berjalan, berbicara, sampai akhitnya kita diajarkan untuk mandiri itu adalah pendidikan yang dilakukan di dalam keluarga. Dalam lingkungan masyarakat kita didik bagaimana cara bersosial dengan orang lain, belajar untuk mematuhi peraturan lingkungan itu adalah salah satu pendidikan yang kita dapatkan dalam masyarakat. Kemudian, disempurnakan dengan peranan pemerintah yang mendirikan sekolah dan juga lembaga yang lain untuk menyempurnakan pendidikan tersebut. Berkenaan dengan tanggung jawab ini pendidikan di sekolah berarti suatu usaha yang sadar akan dilakukan oleh pendidik untuk mempengaruhi siswa dalam rangka pembentukan manusia yang cerdas, kreatif, beragama dan juga berakhlak mulia. Lalu di samping itu, pendidikan sebagai sebuah sistem akan berjalan sesuai dengan fungsinya ketika komponen yang ada dalam pendidikan berjalan secara sinergis. (Tim Pengembang MKDP Kurikulum dan Pembelajaran, 2011, hal. 153) mengemukakan bahwa "seorang pendidik tidaklah melakukan sesuatu tidak tanpa rencana, strategi dalam pembelajaran merupakan salah satu komponen di dalam sistem pembelajaran, yang tidak dapat dipisahkan dari komponen-komponen yang lain di dalamsistem tersebut."

Dengan kata lain, strategi atau komponen dalam pembelajaran dipengaruhi oleh beberapa faktor yaitu: tujuan, bahan (materi), metode (alat), siswa, fasilitas, waktu, serta penilaian (evaluasi). Ketujuh komponen tersebut saling berkaitan dan saling mempengaruhi bahan (materi), demikian juga bahan akan mempengaruhi metode dan penilaian (evaluasi). Sebagai salah satu komponen belajar mengajar, metode mempunyai peranan yang sangat penting karena tanpa metode suatu bahan pelajaran tidak akan berproses secara efektif dan efisien dalam proses belajar mengajar.Dengan menggunakan metode yang akan disampaikan oleh seorang pendidik sangat berpengaruh terhadap prestasi dalam belajar peserta didik, sehingga proses belajar mengajar akan menjadi lebih efektif dan efisien.

Banyak metode dan model pembelajaran yang bisa membuat siswa aktif dalam belajar, bukan hanya aktif dalam belajar, tetapi juga untuk meningkatkan anak dalam berbicara, meningkatkan dalam konsentrasi, meningkatkan dalam berfikir, meningkatkan dalam prestasi belajar siswa. Bukan hanya metode islami yang dilakukan. Dilihat dari segi langkahlangkah dan tujuan kompetensi yang ingin dicapai, terdapat sejumlah metode yang dikemukakan para ahli. Yaitu metode ceramah, tanya jawab, demonstrasi, simulasi, eksperimen, 
penemuan, dan proyekatau unit (Nata, 2011, hal. 181).

Rahman (2011) mengemukakan bahwa ada beberapa metode pembelajaran yang berpusat kepada guru misalnya Metode Ceramah, Metode Demonstrasi dan juga Metode Tanya Jawab. Sedangkan metode pembelajaran yang berpusat kepada siswa pada saat ini sangatlah banyak dan beragam, misalnyaMetode Diskusi Kelompok, Metode Panel, Metode Buгz. Group,Metode Show and Tell, Metode Role Playing, Metode Socio Drama dan masih banyak lagi metode pembelajaran yang berpusat kepada siswa. Dalam proses belajar mengajar harus ada pendidik yang mengajar dan membimbing siswa dalam melakukan proses belajar mengajar. Guru adalah salah satu unsur manusia dalam proses pendidikan di sekolah. Pendidik dan peserta didik berada dalam satu relasi kejiwaan. Keduanya berada dalam proses interaksi edukatif dengan tugas dan peranan yang berbeda. Guru yang mendidik dan pendidik yang belajar dengan menerima bahan pelakaran dari guru di dalam kelas. Mendidik adalah salah satu usaha yang disengaja untuk membimbing dan membina anak agar menjadi manusia susila yang cakap, aktif-kreatif, dan mandiri.

Hal ini juga dipengaruhi oleh kemampuan pendidik dalam proses belajar mengajar, apakah pendidik tersebut mampu menarik perhatian siswa pada saat mengajar dengan menggunakan sebuah metode pembelajaran ataukah malah membuat siswa jenuh dalam proses belajar tersebut? Pendidik yang mampu atau berhasil dalam proses belajar mengajar juga akan membuat siswa baik pula dalam mencapai prestasi belajarnya, dalam hal ini dikhususkan untuk mata pelajaran akhlak, akhlak merupakan perilaku yang sering dilakukan dalam kehidupan sehari-hari, setiap detik, menit bahkan setiap jam. Maka dari itu penerapan Akhlak dalam kehidupan sehari-hari sangatlah penting. Selain dilakukan dalam kehidupan sehari-hari, dalam mata pelajaran pun diajarkan berakhlak yang baik dan sopan itu bagaimana.

Permasalahan yang terjadi mungkin saja karena proses kegiatan pembelajaran dikelas. Adapun kegiatan pembelajaran yang dilakukan oleh pendidik adalah:

1. Kurangnya antusias dan semangat guru dalam menyampaikan materi pembelajaran

2. Kurang kreatif dalam mendesain kegiatan pembelajaran

3. Suasana pembelajaran yang monoton.

Dari beberapa metode yang sudah dipaparkan sebelumnya, peneliti tertarik untuk menggunakan metode Show and Tell. Metode ini bukan hanya mengash anak mahir dalam berbicara di depan orang banyak, tetapi juga bisa untuk meningkatkan prestasi. Dengan aktivitas yang dilakukan dalam metode ini, siswa dapat lebih mengerti tentang apa yang di sampaikan, karena anaklah yang melakukannya sendiri. Anak memilih, anak yang menemukan dan anak juga yang memberi tahukan kepada temantemannya.

Dari latar belakang tersebut, peneliti tertarik untuk mengkaji permasalahan yang timbul di kelas IV Diniyah Takmiliyah Awaliyah Wasilatunnaja. bagaimana Efektivitas Penggunaan Metode Show and Tell terhadap Peningkatan Prestasi Belajar Siswa pada Mata Pelajaran Akhlak di Madarasah Diniyah Takmiliyah Awaliyah Wasilatunnaja Rancaekek Bandung pada Semester Genap Tahun Ajaran 2015/2016. Metode atau metoda menurut (Umar B. , Ilmu Pendidikan Islam, 2010, hal. 55) berasal dari bahasa Yunani, yaitu metha dan hodos. Metha 
berarti melalui atau melawati dan hodos berarti jalan atau cara. Metode berarti jalan atau cara yang harus dilalui untuk mencapaitujuan. Dalam bahsa Arab, metode disebut thariqah. Mengajar berarti menyajikan atau menyampaikan pelajaran.

Jadi metode mengajar berarti suatu cara yang harus dilalui untuk menyajikan bahan pengajaran agar tercapai tujuan pengajaran. Menurut (Tilaar, 2013, hal. 103), show and tell adalah kegiatan yang mengutamakan kemampuan berkomunikasi sederhana. Tujuan kegiatan ini adalah melatih anak berbicara di depan kelas dan membiasakan anak peka terhadap hal-hal sederhana sehari-hari. Sementara itu, metode show and tell digunakan untuk mengungkap kemampuan, perasaan, dan keinginan anak.Show and Tell memiliki definisi menunjukan dan menceritakan. Sebagaimana yang telah dikemukakan oleh Musfiroh (2011, hal. 5) bahwa pengertian Show and Tell adalah "Sebuah aktifitas bercerita (tell) yang dibarengi dengan aktifitas menunjukan sesuatu keada khalayak (show). Show and Tell adalah aktivitas dasar dari public-speaking. Kegiatan ini dilatihkan kepada anak agar di kemudian hari memiliki kemampuan berbicara kepada khalayak. Selain itu, Show adalah kegiatan atau menunjukan sesuatu kepada audiens dan Tell menjelaskan atau mendeskripsikan sesuatu itu. Deskripsi meliputi bentuk, warna, ukuran komposisi, makna, maksud dan guna unsur."

Musfiroh (2011, hal. 1) juga menjelaskan bahwa metode show and tell mengacu pada tiga bidang utama, yaitu edukasi, musik dan teater. Diantara tiga bidang tersebut, metode show and tell edukatif yang paling diandalkan di negara barat. Metode show and tell dimanfaatkan untuk tiga ranah sekaligus. Tiga ranah tersebut adalah show and tell educative forspeaking (show and tell edukatif untuk berbicara), show and tell educative forrecord playing toys (show and tell untuk bermain dengan mainan), dan show andtell for children's book (show and tell untuk buku anak).

Prestasi belajar menurut Sahrani (2011, hlm. 63) adalah kemampuankemampuan yang dimiliki siswa setelah menerima pengamalan belajarnya. Hasil belajar yang dicapai oleh siswa sangat erat kaitannya dengan belajar san rumusan tujuan yang telah dilaksanakan oleh pendidik sebelumnya. Hal ini dipengaruhi pula oleh guru sebagai perancang belajar.

Prestasi belajar juga dapat diartikan sebagai hasil yang dicapai oleh individu setelah mengalami suatu proses belajar dalam jangka waktu tertentu. Prestasi belajar diartikan juga sebagai kemampuan maksimal yang dicapai seseorang dalam suatu usaha yang menghasilkan pengetahuan atau nilainilai kecakapan.

Syah (2008, hal. 67) mengemukakan, bahwa belajar adalah tahapan perubahan seluruh tingkah laku individu yang relatif menetap, sebagai hasil pengalaman dan interaksi dengan lingkungan yang melibatkan proses kognitif. Prestasi belajar menghasilkan perubahan dipihak siswa, dimana perubahan tersebut merupakan kemampuan dari berbagai bidang yang sebelumnya tidak dimiliki siswa. Prestasi belajar merupakan harapan bagi setiap murid yang sedang mengikuti proses pembelajaran di sekolah serta harapan bagi wali murid dan pendidik. Kata Prestasi belajar adalah suatu pengertian yang terdiri atas dua kata yaitu prestasi dan kata belajar, dimana masing-masing mempunyai arti berbeda. Prestasi belajar banyak didefinisikan, seberapa jauh hasil yang sudah didapat siswa dalam penguasaan tugas-tugas atau materi pelajaran yang diterima dalam waktu tertentu.

Pada umumnya prestasi belajar dinyatakan dalam angka atau huruf untuk membandingkan dengan satu kriteria. 
Prestasi belajar adalah kemampuan bagi murid dalam pencapaian berfikir yang tinggi. Harus dimiliki tiga aspek dalam prestasi belajar yaitu kognitif, aspek afektif dan aspek psikomotor.

Untuk mengungkap hasil belajar atau prestasi belajar pada ketiga ranah tersebut diatas, diperlukan patokanpatokan atau indikator-indikator sebagai petunjuk bahwa seseorang telah berhasil meraih prestasi pada tingkat tertentu dari ketiga ranah tersebut. Dalam hal ini (Syah, 2008, hal. 150)mengemukakan bahwaKunci pokok untuk memperoleh ukuran dan data hasil belajar siswa sebagaimana yang terurai diatas adalah mengetahui garis-garis besar indikator (petunjuk adanya prestasi tertentu) dikaitkan dengan jenis prestasi yang hendak diungkapkan atau diukur. Pengetahuan dan pemahaman yang mendalam mengenai indicator-indikator prestasi belajar sangat diperlukan ketika seseorang akan menggunakan alat dan kiat evaluasi. Ada beberapa alternatif norma pengukuran prestasi belajar sebagai indikasi keberhasilan belajar siswa setelah mengikuti proses belajar mengajar. (Tohirin, 2005, hal. 131) menyebutkan norma-noema pengukuran prestasi belajar tersebut adalah:
a. Pertama, norma skala angka dari 0 sampai 10;
b. Kedua, norma skala angka dari 0 sampai 100;
c. Ketiga, norma dari skala angka 0,0 sampai 4,0;
d. Keempat, norma skala huruf A sampai E.

Angka terendah yang menyatakan kelulusan atau keberhasilan belajar (passing grade) skala 0-10 adalah 5 atau 6, sedang untuk skala 0-100 adalah 55 atau 60, untuk skala $0,0-4,0$ adalah 1,0 atau 1,2, dan untuk skala huruf adalah D. Berdasarkan norma-norma ukuran di atas, tidak ada keharusan bagi pendidik termasuk yang mengajar pendidikan agama Islām untuk menggunakan satu norma di atas sebagai acuan dalam memberikan ukuran prestasi belajar siswa,

Ukuran Prestasi Belajar

\begin{tabular}{|c|c|c|}
\hline Angka & Huruf & Predikat \\
\hline $8-10,80-$ & A & Baik Sekali \\
\hline $100,3,5-4,0$ & & \\
\hline $7-9,70-$ & B & Baik \\
$90,2,8-3,4$ & & \\
\hline $5-6,50-$ & C & Cukup \\
\hline $60,1,6-2,5$ & & \\
\hline $3-4,30-$ & D & Kurang \\
$40,1,0-1,5$ & & \\
\hline $0-20,00-$ & E & Gagal \\
\hline $20,0,0-0,9$ & & \\
\hline
\end{tabular}

Sepanjang sesuai dengan aturan yang ditetapkan oleh lembaga yang berwenang.

Akhlak adalah sesuatu yang tidak akan pernah terlepas dari manusia, tanpa akhlak manusia akan melakukan sesuatu yang tidak akan pernah di ridhoi Allah. Dengan pendidikan akhlak, maka kita pasti akan mengetahui antara perbuatan yang baik yang baik dan juga dan buruk, yang hak dan yang batil. Meninggalkan perbuatan yang baik dan meninggalkan perbuatan yang buruk. Maka dari itu penelit akan membahas mengenai "Akhlak Mazmumah kepada Diri sendiri I dan Akhlak Mazmummah kepada Diri sendiri II."yang terdapat dalam buku mata pelajaran akhlak untuk Diniyah Takmiliyah Awaliyah berdasarkan kurikulum Diniyah Takmiliyah Awaliyah 2010 oleh (Sy, 2013, hal. 53).

\section{METODE PENELITIAN}

Dalam penelitian ini, peneliti menggunakan metode eksperimen dengan pendekatan kuantitatif. Salah satu metode dalam peneltian kuantitatif. Menurut Sugiyono (2015, hal. 13) mengemukakan bahwa metode kuantitatif dinamakan metode tradisional, karena metode ini data yang di 
kumpulkan dalam penelitian berupa angka-angka dan analisis dengan menggunakan statistik. Penelitian ini menggunakan eksperimen yang dilakukan untuk mencari pengaruh perlakuan tertentu dalam kondisi yang dikendalikan. Dalam penelitian eksperimen terdapat suatu perlakuan atau yang disebut juga dengan treatment yang diberikan pada kelas atau kelompok eksperimen.

Dalam penelitian ini yang menjadi subjek populasinya adalah seluruh siswa kelas IV Diniyah Takmiliyah Awaliyah Wasilatunnaja yang dijelaskan pada tabel berikut:

\begin{tabular}{|c|c|c|c|}
\hline \multicolumn{4}{|c|}{ Anggota Populasi Penelitian } \\
\hline \multirow[b]{2}{*}{ No. } & \multirow[b]{2}{*}{ Kelas } & \multicolumn{2}{|c|}{ Jumlah } \\
\hline & & $\begin{array}{c}\text { Laki- } \\
\text { laki }\end{array}$ & Perempuan \\
\hline 1 & IV-A & 12 & 12 \\
\hline 2 & IV-B & 12 & 12 \\
\hline 3 & IV-C & 4 & 6 \\
\hline \multicolumn{2}{|c|}{ Jumlah } & 28 & 30 \\
\hline
\end{tabular}

Sumber: Data Kurikulum Diniyah Takmiliyah Awaliyah 2015/2016

Sedangkan yang dijadikan sebagai sampel adalah siswa kelas IV-A dan IV$B$ dengan keterangan jumlah siswa sebagai berikut :

Anggota Sampel Penelitian

\begin{tabular}{|c|c|c|c|}
\hline \multirow[b]{2}{*}{ No } & \multirow[b]{2}{*}{ Kelas } & \multicolumn{2}{|c|}{ Jumlah } \\
\hline & & $\begin{array}{c}\text { Laki- } \\
\text { laki }\end{array}$ & Perempuan \\
\hline 1. & IV-A & 12 & 12 \\
\hline 2. & IV-B & 12 & 12 \\
\hline \multicolumn{2}{|c|}{ Jumlah } & 24 & 34 \\
\hline
\end{tabular}

Sampel pada penelitian ini adalah siswa yang berada pada kelas IV-A yang ditentukan sebagai kelas eksperimen dan IV-B yang ditentukan sebagai kelas kontrol. Dalam penelitian ini, sampel diambil dengan menggunakan nonprobability sampling yakni pengambilan sampel yang tidak memberi peluang/kesempatan sama bagi setiap unsur atau anggota populasi untuk dipilih menjadi sampel. Tekhnik pengambilan sampel dalam penelitian ini adalah purposive sampling atau sampel bertujuan.

Adapun instrumen penelitian yang digunakan adalah Instrumen evaluasi, yaitu berupa tes obyektif materi Akhlak Mazmumah kepada diri sendiri I dan II (malas, sombong, boros, ria, tamak, penakut dan mementingkan diri sendiri), tes ini diujikan pada saat pretest dan posttest. Pretest dilakukan untuk mengetahui kemampuan siswa sebelum diberi perlakuan khusus yaitu penggunaan metodeshow and tell. Sedangkan posttest diajukan untuk mengetahui kemampuan siswa setelah diberiperlakuan. Untuk mengusahakan agar perbandingan hasil test diandalkan, maka pretest dan postest dilakukan menggunakan test yang sama. Soal-soal yang terdapat pada pretest dan posttest yaitu berupa soal pilihan ganda sebanyak 50 soal yang dibuat sendiri oleh peneliti berdasarkan kurikulum DTA 2010 kelas IV yang ada di sekolah tersebut. Penlilaian test obyektif ini didasarkan atas jawaban yang tepat. Setiab jawaban benar memiliki bobot 1 Dan setiap jawaban yang salah memiliki bobot 0 .

Analisis data dalam penelitian ini menggunakan statistik. Selanjutnya, aktivitas dalam analisis data yaitu:

\section{Statistik Deskriptif}

Dengan cara mendeskripsikan atau menggambarkan data yang telah terkumpul berupa tabel, grafik, diagram lingkaran, pictogram, dan angka-angka lainnya. Data yang dianalisis secara deskriptif adalah data hasil belajar siswa berikut peningkatannya (Sugiyono, 2015, hal. 207).

Untuk menginterpretasikan nilai tersebut, digunakan interpretasi sesuai Permendikbud No. 104 Tahun 2014 Interpretasi dapat dilihat pada tabel berikut. 


\begin{tabular}{|c|c|c|c|}
\hline $\begin{array}{l}\text { INTERVAL } \\
\text { NILAI }\end{array}$ & $\begin{array}{c}\text { HASIL } \\
\text { KONVERSI }\end{array}$ & PREDIKAT & INTERPRETASI \\
\hline $96-100$ & 4,00 & A & \multirow{2}{*}{ Sangat baik } \\
\hline $91-95$ & 3,66 & A- & \\
\hline $85-90$ & 3,33 & $\mathrm{~B}+$ & \multirow{3}{*}{ Baik } \\
\hline $80-84$ & 3,00 & B & \\
\hline $75-79$ & 2,66 & B- & \\
\hline $70-74$ & 2,33 & $\mathrm{C}+$ & \multirow{3}{*}{ Cukup } \\
\hline $65-69$ & 2,00 & C & \\
\hline $60-64$ & 1,66 & C- & \\
\hline $55-59$ & 1,33 & $\mathrm{D}+$ & \multirow{2}{*}{ Kurang } \\
\hline$\leq 54$ & 1,00 & $\mathrm{D}$ & \\
\hline
\end{tabular}

Tabel 1

Predikat dan Interpretasi Nilai

\section{Gain Ternormalisasi}

Analisis data gain ternormalisasi digunakan untuk mengetahui ada atau tidaknya peningkatan nilai dari kelas eksperimen dan kontrol. Peningkatan ini dilihat dari nilai pre-test dan post test dari masing-masing kelas. Adapun rumus untuk mencari gain ternormalisasi menurut (Hake, 1998, hal. 68)adalah :

$$
G T=\frac{\text { Npre }- \text { Npost }}{\text { Nmaks }- \text { Npre }}
$$

Keterangan :

GT = Gain ternormalisasi

Npre $=$ Nilai pre-test

Npost $=$ Nilai post test

Nmaks $=$ Nilai maksimum

Adapun interpretasi dari gain ternormalisasi adalah sebagai berikut:

Tabel 2

Interpretasi Gain Ternormalisasi

\begin{tabular}{|c|c|}
\hline GAIN & INTERPRETASI \\
\hline $\mathrm{g} \geq 0,7$ & Tinggi \\
\hline $0,7>\mathrm{g} \geq 0,3$ & Sedang \\
\hline $\mathrm{g}<0,3$ & Rendah \\
\hline \multicolumn{2}{|c|}{ Sumber : (Hake, 1998, hal. 68) } \\
Uji Hipotesis
\end{tabular}

Sebelum data yang diperoleh digunakan untuk menguji hipotesis dalam penelitian, data tersebut harus berdistribusi normal dan homogen. Dalam hal ini, data yang didapat dari data pre-test dan data post-test, masingmasing dilakukan uji normalitas dan uji homogenitasnya. Adapun rinciannya adalah :

a. Uji Normalitas

Tujuan dari uji normalitas adalah untuk mengetahui apakah data yang dipakai berdistrubusi normal atau tidak normal. Adapun beberapa teknik yang dapat digunakan dalam pengujian normalitas data antara lain, melalui rumus Kolmogorov-Smirnov, Shapiro-Wilk, Chi Square atau Chi Kuadrat dan sebagainya.

Dalam penelitian ini, peneliti menggunakan uji Chi Square untuk menguji normalitas data. Adapun langkah-langkah pengujian normalitas data menggunakan uji $C h i$ Square meliputi :

1) Merumuskan Hipotesis

$\mathrm{H}_{\mathrm{o}}=$ Data berdistribusi normal

$\mathrm{H}_{\mathrm{a}}=$ Data berdistribusi tidak normal

2) Kriteria Pengujian Hipotesis

Dalam pengujian hipotesis uji normalitas data dengan Chi Square, ada beberapa kriteria yang dapat digunakan, yaitu ;

a) Dengan membandingkan antara nilai chi kuadrat ${ }_{\text {hitung }}$ dengan chi kuadrat $_{\text {tabel. }}$ Adapun ketentuannya adalah jika nilai chi kuadrat ${ }_{\text {hitung }}<$ chi kuadrat tabel $_{\text {maka }} \mathrm{H}_{\mathrm{o}}$ diterima dan $\mathrm{H}_{2}$ ditolak, berarti data berdistribusi normal, sedangkan jika nilai chi kuadrat $t_{\text {hitung }}>$ chi kuadrat $_{\text {tabel }}$ maka $\mathrm{H}_{\mathrm{o}}$ ditolak dan $\mathrm{H}_{\mathrm{a}}$ diterima, berarti data berdistribusi tidak normal.

b) Dengan melihat signifikansi asymp. Signifikansi asymp ini dapat dilihat dari output SPSS pengolahan data dengan Chi Square. Adapun ketentuannya adalah jika nilai signifikansi asymp $>0,05$ maka data berdistribusi normal, sedangkan jika nilai signifikansi asymp $<0,05$ maka data berdistribusi tidak normal. 
3) Cara menghitung Chi Square Untuk menghitung nilai Chi Square secara manual, dapat menggunakan rumus berikut:

Keterangan :

$$
\chi^{2}=\sum_{i=1}^{k} \frac{(f o-f e)^{2}}{f e}
$$

$\mathrm{x}^{2}=$ Chi Kuadrat

fo $=$ Frekuensi hasil observasi dari sampel penelitian

$\mathrm{fe}=$ Frekuensi yang diharapkan pada populasi penelitian, dengan membagikan jumlah subjek dalam sampel dengan kategori subjek.

\section{b. Uji Homogenitas Fisher}

Uji homogenitas fisher digunakan untuk menguji signifikasi hipotesisdua sampel kecil independen bila datanya Chi Kuadrat bertujuan untuk mengetahui apakah varian populasi sama (homogen) atau tidak (Sugiyono, Metode Penelitian Bisnis, 2009, hal. 316)

1) Merumuskan hipotesis

$\mathrm{H}_{\mathrm{o}}$ : data memiliki varian yang sama (homogen)

$\mathrm{H}_{\mathrm{a}}$ : data tidak memiliki varian yang sama

2) Kriteria Pengujian Hipotesis

Jika $\mathrm{F}_{\text {hitung }}<\mathrm{F}_{\text {Tabel }}$, maka $\mathrm{H}_{\mathrm{o}}$ diterima

3) Cara hitung

$$
F_{\text {hitung }}=\frac{\text { Varians terbesar }}{\text { Varians terkecil }}
$$

Untuk menghitung uji homogenitas, peneliti menggunakan bantuan program SPSS versi 21.

Adapun cara lain untuk menghitung uji homogenitas yaitu dengan meng- gunakan Uji Fisher, uji Fisher digunakan hanya pada 2 kelompok data.

Langkah-langkah pada Uji Fisher adalah sebagai berikut:

a) Tentukan taraf signifikansi $(\alpha)$ untuk menguji hipotesis:

Ho : $\sigma^{2}{ }_{1}=\sigma^{2}{ }_{1}$ (varians 1 sama dengan varians 2 atau homogen)

$\mathrm{Ha}: \sigma^{2}{ }_{1} \neq \sigma^{2}{ }_{1}$ (varians 1 tidak sama dengan varians 2 atau tidak homogen)

Dengan kriteria pengujian:

Jika $\mathrm{F}_{\text {hitung }}<\mathrm{F}_{\text {tabel, }}$ maka Ho

Terima

Jika $F_{\text {hitung }}>F_{\text {tabel, }}$ maka Ho Di

tolak

b) Menghitung varians tiap kelompok data.

c) Tentukan nilai $F_{\text {hitung, yaitu }} F_{\text {hitung }}$ $=\underline{\text { Varians terbesar }}$

Varians terkecil

d) Tentukan Ftabel untuk taraf signifikansi $\alpha \mathrm{dk} 1=\mathrm{dk}_{\text {pembilang }}=$ $\mathrm{na}-1, \mathrm{dan} \mathrm{dk} 2=\mathrm{dk}_{\text {penyebut }}=\mathrm{nb}$ -1 .

e) Lakukan pengujian dengan membandingkan nilai $\mathrm{F}_{\text {hitung }}$ dan $\mathrm{F}_{\text {tabel. }}$.

c. Pengujian Hipotesis : Uji Beda

Pengujian hipotesis dalam penelitian ini menggunakan uji beda. Dimana, ketika data berdistribusi normal, maka menggunakan statistik parametrik, dan ketika data berdistribusi tidak normal maka menggdnakan statistik non parametrik. Sekaitan dengan penelitian ini, ketika data berdistribusi normal, maka rumus statistik yang akan digunakan adalah uji t, karena membandingkan ratarata dari dua kelompok yang berbeda dan jumlah sampel kurang dari 100. 
Uji statistik parametrik dikelompokkan dalam dua pengujian, yaitu :

1) Uji independent samples test

Yaitu membandingkan rata-rata nilai pre-test atau post test pada kelompok yang berbeda. Adapun langkah-langkah pengujian normalitas data menggunakan uji independent samples test meliputi :

a) Menentukan hipotesi

$\mathrm{H}_{\mathrm{o}}=$ Rata-rata hasil belajar pre-test siswa kelas eksperimen dan kontrol adalah sama

$\mathrm{H}_{\mathrm{a}}=$ Rata-rata hasil belajar pre-test siswa kelas eksperimen dan kontrol adalah berbeda.

atau

$\mathrm{H}_{\mathrm{o}}=$ Rata-rata hasil belajar post test siswa kelas eksperimen dan kontrol adalah sama

$\mathrm{H}_{\mathrm{a}}=$ Rata-rata hasil belajar post test siswa kelas eksperimen dan kontrol adalah berbeda.

b) Kriteria Pengujian Hipotesis Jika nilai sig.(2-tailed) $>0,05$, maka $\mathrm{Ho}$ di terima dan Ha di tolak. Sedangkan jika nilai sig.(2-tailed) $<0,05$, maka Ho ditolak dan $\mathrm{Ha}$ diterima.

c) Cara menghitung uji independent samples test

$$
t=\frac{x_{1}-x_{2}}{\sqrt{\frac{\left(n_{1}-1\right) s_{1}^{2}-\left(n_{2}-1\right) s_{2}^{2}}{n_{1}+n_{2}-2}\left(\frac{1}{n_{1}}\right)+\left(\frac{1}{n_{2}}\right)}}
$$

Sumber : (Sugiyono, 2010, hlm. 138)

Keterangan :

$\mathrm{x}_{1} \quad=$ Rata-rata kelompok 1

$\mathrm{x}_{2} \quad=$ Rata-rata kelompok 2

$\mathrm{s}_{1} \quad=$ Standar deviasi kelompok 1

$\mathrm{s}_{2} \quad=$ Standar deviasi kelompok 2

$\mathrm{n}_{1} \quad$ Banyaknya sampel kelompok 1

$\mathrm{n}_{2}=$ Banyaknya sampel kelompok 2
2) Uji paired samples test

Yaitu membandingkan rata-rata nilai pre-test dan post test pada kelompok yang sama. Adapun langkah-langkah pengujian normalitas data menggunakan uji paired samples test meliputi :

a) Menentukan hipotesis

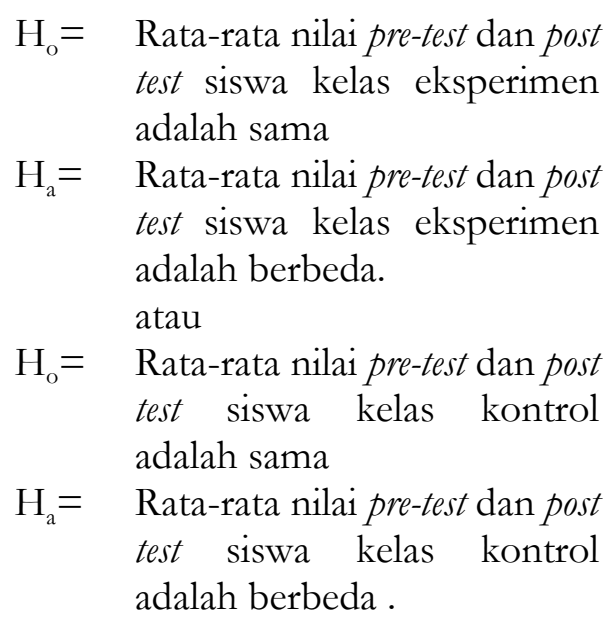

b) Kriteria Pengujian Hipotesis Jika nilai sig.(2-tailed) $>0,05$, maka $\mathrm{H}_{\mathrm{o}}$ di terima dan $\mathrm{H}_{\mathrm{a}}$ di tolak. Sedangkan jika nilai sig.(2-tailed) $<0,05$, maka $\mathrm{H}_{\text {o }}$ ditolak dan $\mathrm{H}_{\mathrm{a}}$ diterima.

c) Cara menghitung uji paired samples test

$$
t=\frac{x_{1}-x_{2}}{\sqrt{\frac{s_{1}^{2}}{n_{1}}+\frac{s_{2}^{2}}{n_{2}}-2 r\left(\frac{s_{1}}{\sqrt{n_{1}}}\right)\left(\frac{s_{2}}{\sqrt{n_{2}}}\right)}}
$$

Sumber : (Sugiyono, 2010, hlm. 122)

Sementara, uji statistik non parametrik dikelompokkan dalam dua pengujian sebagai berikut :

\section{1) Uji Mann Whitney}

Sama halnya dengan uji independent samples test, uji mann whitney juga digunakan untuk membandingkan ratarata nilai pre-test atau post test pada kelompok yang berbeda.

Ketentuan pengujian hipotesis yaitu $\mathrm{H}_{\mathrm{o}}$ diterima dan $\mathrm{H}_{\mathrm{a}}$ ditolak jika $\mathrm{U}_{\text {hitung }}<$ 
$\mathrm{U}_{\text {tabel}}$, sedangkan jika $\mathrm{U}_{\text {hitung }}<\mathrm{U}_{\text {tabel }}$ maka $\mathrm{H}_{\mathrm{o}}$ ditolak dan $\mathrm{H}_{\mathrm{a}}$ diterima. Adapun rumus $\mathrm{Uji} U$ adalah sebagai berikut :

$$
\begin{aligned}
& U_{1=} n_{1} n_{2}+\frac{n_{1\left(n_{1}+1\right)}}{2}-R_{1} \\
& U_{2}=n_{1} n_{2}+\frac{n_{2\left(n_{2}+1\right)}}{2}-R_{2}
\end{aligned}
$$

Sumber : (Sugiyono, 2010, hlm. 153)

\section{Keterangan:}

$n_{1}=$ ukuran sampel yang pertama

$n_{2}=$ ukuran sampel yang kedua

$\mathrm{U}_{1}=$ jumlah peringkat 1

$\mathrm{U}_{2}=$ jumlah peringkat 2

$R_{1}=$ peringkat (rank) sampel yang pertama

$R_{2}=$ peringkat (rank) sampel yang kedua

\section{2) Uji Wilcoxon}

Uji wilcoxon ini digunakan untuk membandingkan rata-rata nilai pre-test dan post test pada kelompok yang sama. Sama halnya seperti uji paired samples test.

Ketentuan penguiian hipotesis yaitu, jika To $\geq \mathrm{T}$ maka Ho diterima dan Ha ditolak. Jika To $<\mathrm{T}$ maka Ho ditolak dan $\mathrm{Ha}$ diterima. Adapun rumus Uji z adalah sebagai berikut :

$Z=\frac{T-E(T)}{\sigma_{T}}$

Sumber : (V \& Endrayanto, 2012, hal. 156)

Untuk keseluruhan pengolahan analisis data, dalam penelitian ini menggunakan bantuan software SPSS 21 untuk menghitung data uji normalitas dan uji t-test. Sedangkan untuk uji homogenitas, menggunakan Microsoft Office Excel 2013.

\section{HASIL PENELITIAN DAN PEMBAHASAN}

Berdasarkan hasil penelitian, ditemukan bahwa yang memiliki nilai interpretasi sangat baik ada 0 siswa atau $0 \%$ dari jumlah seluruh siswa yang melakukan pretest di kelas eksperimen, sedangkan 8 siswa memiliki interpretasi nilai baik atau $33 \%$ dari jumlah seluruh siswa yang melakukan pretest di kelas eksperimen, kemudian interpretasi nilai cukup terdapat 12 orang atau $50 \%$ dari jumlah seluruh siswa yang melakukan pretest di kelas eksperimen, dan interpretasi nilai terdapat 4 siswa atau $17 \%$ dari jumlah seluruh siswa yang melakukan pretest di kelas eksperimen.

Kemudian diketahui siswa yang memiliki interpretasi nilai sangat baik terdapat 0 siswa atau $0 \%$, sedangkan siswa yang memiliki interpretasi nilai baik terdapat 6 siswa atau $25 \%$ kemudian interpretasi nilai cukup terdapat 10 siswa atau $42 \%$, interpretasi nilai kurang terdapat 8 siswa atau 33\% untuk kelas kontrol.

Adapun pengolahan data untuk uji independent sample t-test, dibantu dengan aplikasi SPSS 21 sebagai berikut :

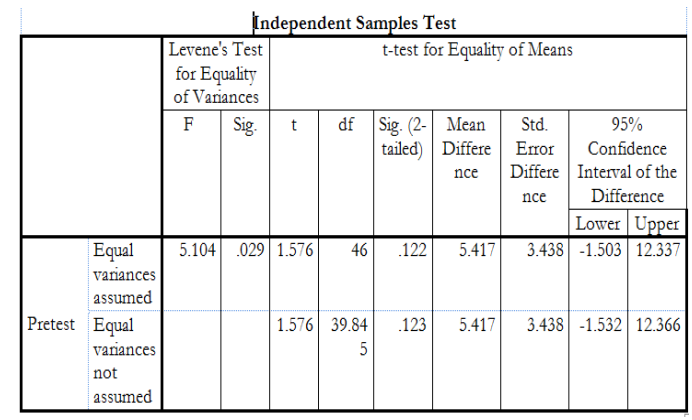

Tabel 3

Output Independent Samples t-test Pre-test

Berdasarkan hasil diatas, karena data normal tetapi tidak homogen, maka nilai sig yang digunakan adalah nilai baris kedua (Equal variances not assumed) diperoleh nilai sig (2-tailed) sebesar 0,123 dengan (df) 39,845 dimana 0,123 >0,05. Maka sesuai dasar pengambilan keputusan dalam uji independent sample ttest maka dapat disimpulkan $\mathrm{H}_{\mathrm{o}}$ diterima dan $\mathrm{H}_{\mathrm{a}}$ ditolak yang artinya bahwa tidak terdapat perbedaan antara rata-rata nilai hasil belajar pretest kelas eksperimen dan kelas kontrol. Dengan demikian, berdasartkan perhitungan statistik 
kemampuan kelas kontrol dengan kelas eksperimen diasumsikan sama.

Diketahui dalam kelas eksperimen bahwa siswa yang memiliki interpretasi nilai sangat baik ada 5 orang siswa (21\%), sedangkan interpretasi nilai baik ada 13 orang siswa (54\%), pada interpretasi nilai cukup ada jumlah 5 orang siswa (21\%), dan untuk interpretasi nilai kurang tidak ada atau 1 siswa (4\%).

Sedangkan untuk kelas kontrol diketahui bahwa siswa yang memiliki interpretasi nilai sangat baik ada 2 orang siswa $(8 \%)$, sedangkan interpretasi nilai baik ada 12 orang siswa (50\%), pada interpretasi nilai cukup tidak ada atau 7 siswa $(29 \%)$, dan untuk interpretasi nilai kurang ada atau 3 siswa (13\%).

Pengolahan data dengan gain ternormalisasi, menunjukkan kelas eksperimen mengalami peningkatan pemahaman belajar sebanyak 0,09 dengan interpretasi rendah. Untuk mengetahui apakah peningkatan yang terjadi meningkat secara signifikan atau tidak, maka data pre-test dan post test diuji dengan uji paired sample test, dengan syarat data berdistribusi normal dan homogen.

Setelah data pre-test dan post test diketahui normal dan homogen, maka data akan dihitung dengan uji paired sample test. Adapun perhitungannya dibantu dengan aplikasi SPSS 21 sebagai berikut :

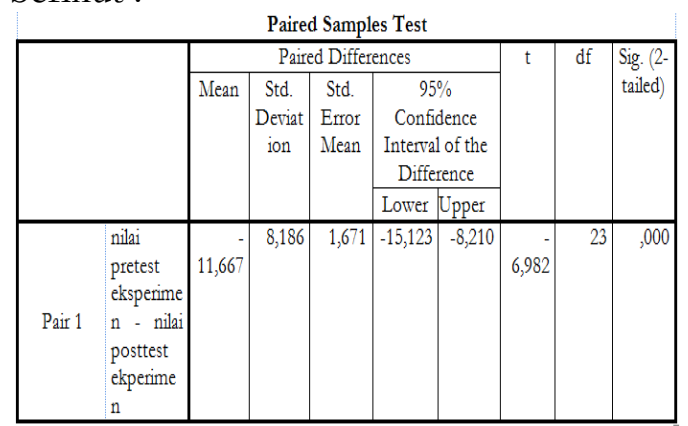

Tabel 4

Output Uji Paired Sample Test

Kelas Eksperimen

Berdasarkan hasil di atas, diperoleh bahwa nilai sig. (2-tailed) sebesar 0,000 dan $\mathrm{df}=$ sebesar 23, maka $0,000<$ 0,05 sesuai dasar pengambilan keputusan dalam uji paired sample t-test, dapat disimpulkan dengan melihat kriteria pengujian Jika signifikasi $>0,05$ maka $\mathrm{H}_{\circ}$ diterima dan $\mathrm{H}_{\mathrm{a}}$ ditolak sedangkan Jika signifikasi $<0,05$ maka $H_{o}$ ditolak dan $\mathrm{H}_{a}$ diterima. Jika dilihat dari TJika $\mathrm{T}_{\text {hitung }}<\mathrm{T}_{\text {table }}$ maka Ho ditolak, Jika $\mathrm{T}_{\text {hitung }}>\mathrm{T}_{\text {table }}$ maka Ho diterima, maka hasil $\mathrm{T}-6,982<1.714$, dapat disimpulkan bahwa terdapat perbedaan rata-rata yang diperoleh dalam peningkatan prestasi belajar.peningkatan prestasi belajar yang didapat oleh kelas eksperimen yaitu setelah melaksanakan proses pembelajaran dengan menggunakan metode show and tell.

Sedangkan pengolahan data dengan gain ternormalisasi, menunjukkan kelas kontrol mengalami peningkatan pemahaman belajar sebanyak 0,08 dengan interpretasi rendah. Untuk mengetahui apakah peningkatan yang terjadi meningkat secara signifikan atau tidak, maka data pre-test dan post test diuji dengan uji paired sample test, dengan syarat data berdistribusi normal dan homogen.

Setelah data pre-test dan post test diketahui normal dan homogen, maka data akan dihitung dengan uji paired sample test. Adapun perhitungannya dibantu dengan aplikasi SPSS 21 sebagai berikut :

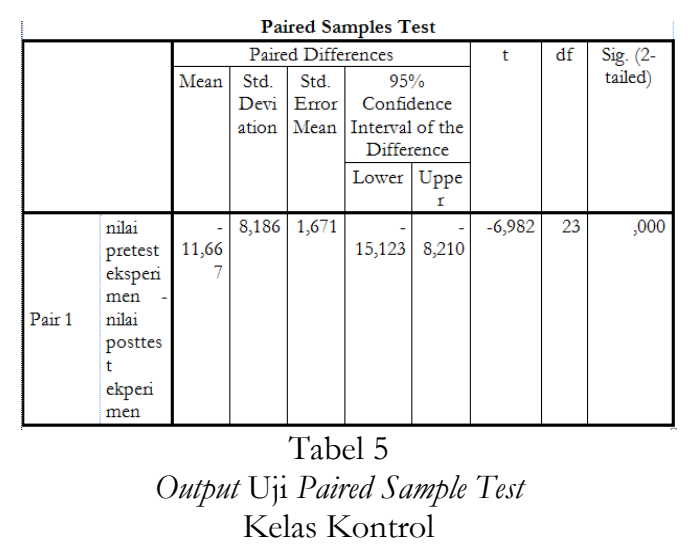


Berdasarkan hasil di atas, diperoleh bahwa nilai sig. (2-tailed) sebesar 0,000 dan $\mathrm{df}=$ sebesar 23, maka $0,000<$ 0,05 sesuai dasar pengambilan keputusan dalam uji paired sample t-test, dapat disimpulkan dengan melihat kriteria pengujian Jika signifikasi $>0,05$ maka diterima dan $\mathrm{H}_{a}$ ditolak sedangkan Jika signifikasi $<0,05$ maka $\mathrm{H}_{\text {o }}$ ditolak dan $\mathrm{H}_{a}$ diterima. Jika dilihat dari TJika $\mathrm{T}_{\text {hitung }}<\mathrm{T}_{\text {table }}$ maka Ho ditolak, Jika $\mathrm{T}_{\text {hitung }}>\mathrm{T}_{\text {table }}$ maka Ho diterima, maka hasil $\mathrm{T}-5,622<1.714$, dapat disimpulkan bahwa terdapat perbedaan rata-rata yang diperoleh dalam peningkatan prestasi belajar. peningkatan prestasi belajar yang didapat oleh kelas eksperimen yaitu setelah melaksanakan proses pembelajaran dengan menggunakan metode show and tell.

Untuk mengetahui efektif atau tidaknya metodeshow and tell, dilakukan uji independent sample t-test.Adapun data yang akan digunakan untuk pengujian hipotesis dengan uji independent sample ttest yaitu menggunakan data nilai dari posttest kelas eksperimen dan data nilai post test kelas kontrol.

Salah satu syarat menggunakan uji-t adalah data berdistribusi normal dan homogen, Untuk pengujian normalitas data posttest kelas eksperimen, telah disebutkan sebelumnya, diketahui bahwa nilai chi kuadrat ${ }_{\text {hitung }}$ lebih kecil dari chi kuadrat $_{\text {tabel }}$ yaitu5,250<21.02606, maka distribusi data posttest kelas eksperimen tersebut normal.

Sedangkan pengujian normalitas posttest kelas kontrol, dapat dilihat pada tabel 4.23, diketahui nilai chi kuadrat ${ }_{\text {hitung }}$ lebih kecil dari chi kuadrat ${ }_{\text {tabel }}$ yaitu 4,000 $<22.36203$, maka distribusi data posttest kelas kontrol tersebut normal. Sementara untuk pengujian homogenitas posttest kelas eksperimen dan kontrol, telah dijelaskan sebelumnya, bahwa nilai $\mathrm{F}_{\text {hitung }}$ lebih kecil dari $\mathrm{F}_{\text {tabel }}$ yaitu 1,44<2,01, dengan demikian dapat dinyatakan bahwa varian kelompok data posttest kelas eksperimen dan kontrol tersebut homogen.Setelah diketahui bahwa data terdistribusi normal dan homogen, maka dapat dilakukan uji independent sample t-test.Adapun perhitungannya dibantu dengan aplikasi SPSS 21 sebagai berikut :

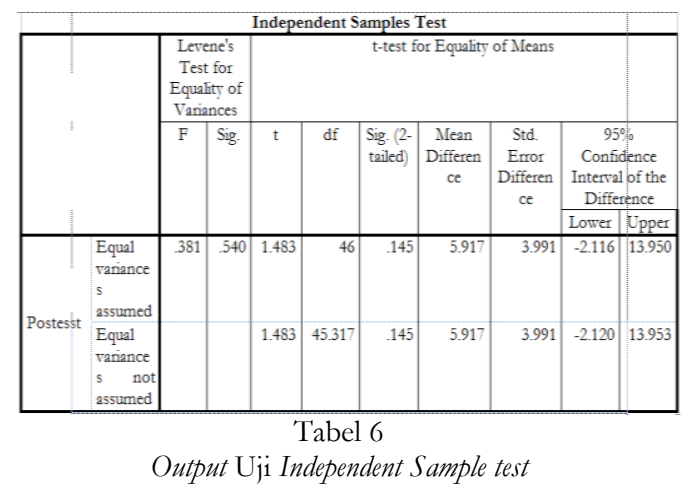

Berdasarkan hasil diatas, karena data normal dan homogen, maka nilai sig yang digunakan adalah nilai baris pertama (Equal variances assumed) diperoleh nilai sig (2-tailed) sebesar 0,145 dengan (df) 46dimana 0,145>0,05. Maka sesuai dasar pengambilan keputusan dalam uji independent sample ttest maka dapat disimpulkan $\mathrm{H}_{\mathrm{o}}$ diterima dan $\mathrm{H}_{\mathrm{a}}$ ditolak yang artinya bahwa tidak terdapat perbedaan antara rata-rata prestasi belajar kelas eksperimen dan kelas kontrol.Yang juga menunjukkan bahwa tidak ada perbedaan yang signifikan hasil belajar antara kelas eksperimen dan kelas kontrol. Dengan kata lain metode show and tell ini tidak efektif dalam meningkatkan hasil belajar siswa pada mata pelajara akhlak.

\section{KESIMPULAN}

Berdasarkan uji hipotesis, dapat ditarik kesimpulan bahwa kurangnya peningkatan yang signifikan antara nilai posttest antara kelas eksperimen yang menggunakan metode show and tell dan kelas kontrol yang tidak menggunakan metode show and tell. Yang juga menunjukkan 
bahwa tidak ada perbedaan yang signifikan peningkatan hasil belajar antara kelas eksperimen dan kelas kontrol. Ternyata metode show and tell ini tidak efektif dalam meningkatkan prestasi belajar siswa pada mata pelajaran akhlak khususnya pada sub bahasan akhlak marmumah I dan akhlak mazmumah II. Peneliti menduga bahwa dengan hasil yang tidak efektif di akibatkan materi pembelajaran yang sangat mudah dipelajari dan dipahami oleh anak sehingga hasil yang didapatkan yaitu tidak efektif.

\section{REFERENSI}

Hake, R. R. (1998). Interactiveengagement versus traditional methods: A six-thousand-student survey of. American Journal of Physics, 1 (66), 64-74.

Musfiroh, T. (2011). Show and Tell Edukatif. Panduan Pengembangan Social Skill Anak Usia Dini. Yogyakarta: Lokus.

Nata, A. (2011). Perspektif Islam tentang Strategi Pembelajaran. Jakarta: Kencana.

Rahman, I. O. (2011, April 20). Komunitas Guru Sekolah Dasar. Retrieved Februari 12, 2015, from http://komunitasgurusekolahdas arwakatobi.blogspot.co.id/p/30metode-pembelajaran.html

Sugiyono. (2009). Metode Penelitian Bisnis. Bandung: Alfabeta.

Sugiyono. (2015). Metode Penelitian Pendidikan Pendekatan Kuantitatif, Kualitatif, dan R\&D. Bandung: Alfabeta.

Suryadi, R. A. (2011). Hadits: Sumber Pemikiran Pendidikan. Jurnal Pendidikan, 5(2), 154-170.

Sy, W. (2013). Mari Belajar Akblak (Diniyah Takmiliyah Awaliyah) untuk kelas IV Smester 1 \& 2. Bandung: CV. Rizqi.
Syah, `. (2008). Psikologi Pendidikan dengan Pendekatan Baru. Bandung: Remaja Rosdakarya.

Tilaar, H. A. (2013). Media Pembelajaran Aktif. Bandung: Nuansa Cendekia.

Tim Pengembang MKDP Kurikulum dan Pembelajaran. (2011). Kurikulum dan Pembelajaran. Bandung: PT Rajagrafindo Persada.

Tohirin. (2005). Psikologi Pembelajaran Pendidikan Agama Islam. Jakarta: PT Raja Grafindo Persada.

Umar, B. (2010). Ilmu Pendidikan Islam. Jakarta: Amzah.

V, W. S., \& Endrayanto, P. (2012). Statistika untuk Penelitian. Yogyakarta: Graha Ilmu. 